\title{
New Distributional, Host and Plant Association Records of Saproxylic Ichneumonid Parasitoids (Hymenoptera, Ichneumonidae) in Turkey
}

\author{
Oleksandr VARGA ${ }^{1}$ \\ Halil BOLU ${ }^{2}$ \\ ${ }^{1}$ I. I. Schmalhausen Institute of Zoology, National Academy of Sciences \\ of Ukraine Bogdan Chmielnitski St. 15, 01630 Kyiv, UKRAiNE \\ ${ }^{2}$ Dicle University, Faculty of Agriculture, Department \\ of Plant Protection 21280 Diyarbakır, TURKEY

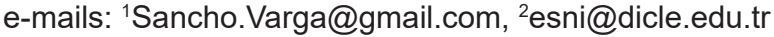 \\ ORCID IDs: ${ }^{10000-0002-6285-7830, ~}{ }^{20000-0001-5488-0056 ~}$
}

\begin{abstract}
The present study was carried out in Diyarbakır Province (N 3753'36.96”, E 40¹6'13.65”, $666 \mathrm{~m}$ ) in Southeastern Anatolia Region of Turkey in 2018-2020. Prunus cerasifera tree parts infested by the buprestid beetle, Ptosima undecimmaculata, were cut in June 2018 and February 2019 (Figs. 1-2) and Prunus persica infested by buprestids larvae, Ptosima undecimmaculata (Herbst, 1784) and Sphenoptera (Tropeopeltis) tappesi Marseul, 1865, respecitvely were cut and placed in plastic boxes until host and/ or their potential parasitoids were reared. Three ichneumonid parasitoids, Dolichomitus kriechbaumeri (Schulz, 1906), Poemenia notata Holmgren, 1859 and Xorides gravenhorstii (Curtis, 1831), were obtained. New host records were found: $P$. undecimmaculata for $D$. kriechbaumeri and $S$. tappesi for $X$. gravenhorstii. All three parasitoid species were reared from the studied plants for the first time. P. notata is a new record for Turkish fauna.
\end{abstract}

Key words: Pimplinae, Poemeniinae, Xoridinae, Buprestidae, new record, Turkey.

Varga, O. \& Bolu, H. (2021). New distributional, host and plant association records of saproxylic ichneumonid parasitoids (Hymenoptera, Ichneumonidae) in Turkey. Journal of the Entomological Research Society, 23(2), 173-178. 


\section{INTRODUCTION}

Ichneumonidae is one of the largest insect families represented by almost 25000 described species, of which about 1200 species were recorded from Turkey (Yu, van Achterberg, \& Horstmann, 2016). The Turkish Ichneumonidae fauna was unevenly and relatively poorly studied until the first catalogue was published by Kolarov (1995). He listed a little less than 400 species recorded mostly from Thrace and Egean regions, and Northeastern Turkey, while the Southeastern part of the country remained largely unstudied. Later, an intensive investigation of Ichneumonidae fauna of Eastern Turkey was conducted by J Kolarov, S. Çoruh and coauthors resulting in series of faunistic papers (e.g. Çoruh, 2010; Çoruh \& Kolarov, 2010; Çoruh \& Kolarov, 2013; Kolarov, Çoruh, Yurtcan, \& Gürbüz, 2009). The seasonal dynamics, altitudinal distribution, individual diversities, biogeographical positions and host records of the Eastern Turkish Ichneumonidae were discussed by Çoruh, Kolarov, \& Özbek (2014).

The aim of this paper is to provide new distributional, host and plant association records of ichneumonid parasitoids of the subfamilies Pimplinae, Poemeniinae, Xoridinae from the Southeastern Anatolia Region of Turkey.

\section{MATERIAL AND METHODS}

The present study was carried out in Diyarbakır Province (N 37 53'36.96”, E $40^{\circ} 16^{\prime} 13.65$ ”, $666 \mathrm{~m}$ ) in Southeastern Anatolia Region of Turkey in 2018-2020. Prunus cerasifera tree parts infested by the buprestid beetle, Ptosima undecimmaculata, were cut in June 2018 and February 2019 (Figs. 1-2) and Prunus persica infested by the buprestid species, Sphenoptera tappesi (Fig. 3), were cut in April 2019 and March 2020. All collected logs were stored in plastic boxes with $20 \times 20 \times 30 \mathrm{~cm}$ lids closed with thin mesh fabric at a temperature of $26 \pm 1^{\circ} \mathrm{C}$, relative humidity of $65 \pm 5$, and illumination of 3500 lux for 16 hours per day (Fig. 4). Totally, 84 beetle and 37 parasitoid specimens were reared.

The hymenopteran material from this study is deposited in the collection of the Schmalhausen Institute of Zoology NAS of Ukraine in Kyiv (SIZK). Image of Poemenia notata was taken with a Leica Z16 APO microscope equipped with Leica DFC 450 camera and processed by LAS Core software at SIZK.

\section{RESULTS}

\section{Dolichomitus kriechbaumeri (Schulz, 1906)}

Distribution: Western Palaearctic (Yu et al, 2016), Turkey (Kolarov, 1995; Bolu, 2008).

\footnotetext{
Material examined: Turkey, Diyarbakır, N 3753'36.96”, E 40¹6'13.65”, 666 m, ex Prunus cerasifera logs infested by Ptosima undecimmaculata, 15.06.2018-06.02.2019, leg. H. Bolu, 1 o, 2 o of; idem, ex

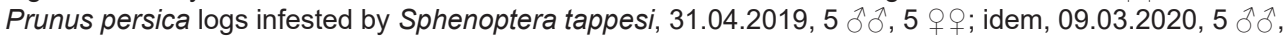
5 우; idem, 10.03.2020, 5 $\widehat{\jmath}, 4$ 우; idem, ex Prunus cerasifera logs infested by Sphenoptera tappesi, 10.03.2020, 2 ふぇ.
} 
New Distributional, Host and Plant Association Records

Poemenia notata Holmgren, 1859 (Figs. 5-6.)

Distribution: Widespread and common species in Western Palaearctic (Yu et al, 2016), new for Turkey.

Material examined: Turkey, Diyarbakır, N 3753'36.96”, E 40¹6'13.65”, 666 m, ex Prunus cerasifera logs infested by Ptosima undecimmaculata, 15.06.2018-06.02.2019, leg. H. Bolu, 1 §.

\section{Xorides gravenhorstii (Curtis, 1831)}

Distribution: Widespread and common species in Western Palaearctic (Yu et al, 2016), Turkey (Kolarov, 1995).

Material examined: Turkey, Diyarbakır, N 3753'36.96”, E 40¹6'13.65”, $666 \mathrm{~m}$, ex Prunus persica logs infested by Sphenoptera (Tropeopeltis) tappesi, 31.04.2019, leg. H. Bolu, 1 ô, 1 q.

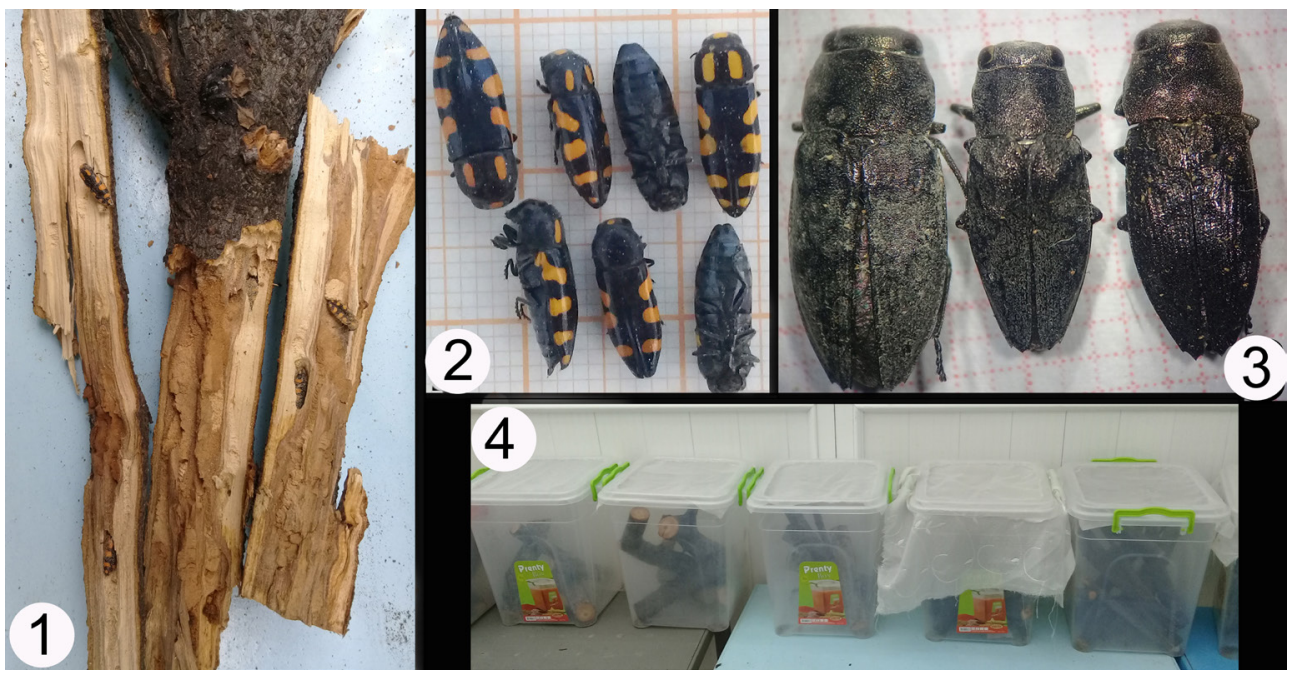

Figs. 1-4. Rearing. 1. Prunus cerasifera parts infested Ptosima undecimmaculata. 2. Reared Ptosima undecimmaculata imago. 3. Reared Sphenoptera tappesi imago. 4. Plastic boxes with infested logs.
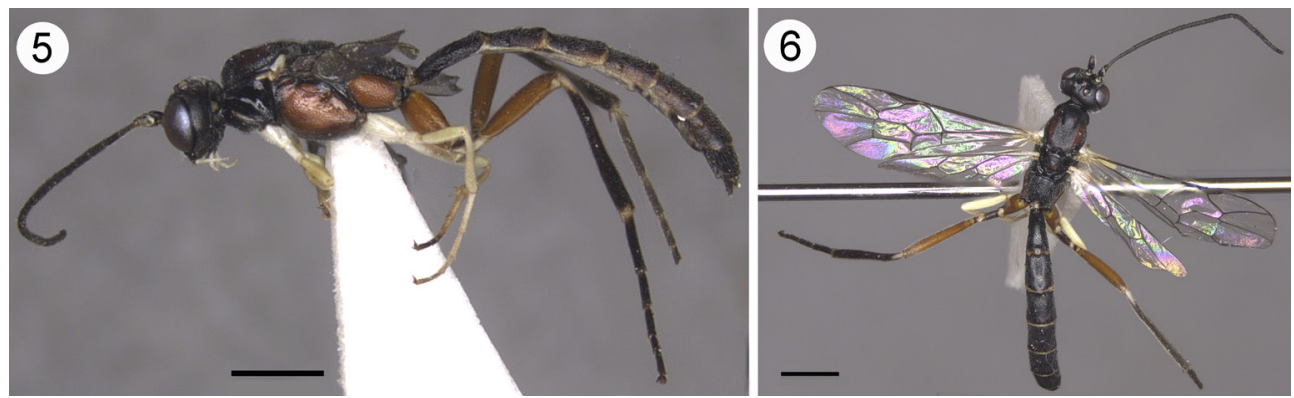

Figs. 5-6. Poemenia notata, male. 5. Lateral view. 6. Dorsal view. 


\section{CONCLUSIONS AND DISCUSSION}

Three ichneumonid species (Hymenoptera: Ichneumonidae) belonging to subfamilies Pimplinae, Poemeniinae, Xoridinae were reared during this study. These species are parasitoids of coleopteran or hymenopteran insect hosts living in the dead wood (Yu et al, 2016).

Pimplinae-wasp, Dolichomitus kriechbaumeri, is one of twenty-five species of the genus known from Western Palaearctic (Zwakhals, 2010; Varga, 2012). Generally, most of Dolichomitus species are reported as ectoparasitoids of different Cerambycidae larvae. Unlike other species, D. kriechbaumeri is a specialized parasitoid of the buprestid beetles (e.g. Zwakhals, 2010). Several buprestid beetle species, Anthaxia manca (Linnaeus, 1767), Sphenoptera tappesi and Trachypteris picta (Pallas, 1773), are listed as hosts in papers of Aubert (1969), Bolu (2008) and Zwakhals (2010). In this study, we provide a new host record for D. kriechbaumeri, a buprestid beetle Ptosima undecimmaculata inhabiting Prunus cerasifera logs. In addition, this tree is a new plant association record for this species.

Another parasitoid of wood-boring beetles reared during this study is a member of the subfamily Xoridinae, Xorides gravenhorstii. It seems that this species is generalist ectoparasitoid of different saproxylic beetle larvae. It is reported as parasitoid of Ptinidae: Hedobia pubescens (Olivier, 1790) (Aubert, 1969), Xestobium plumbeum (Illiger, 1801) (Leclercq, 1945), Bostrichidae: Psoa dubia (Rossi, 1792), Cerambycidae: Phymatodes (Paraphymatodes) fasciatus (Villers, 1789) (Aubert, 1969), Pogonocherus hispidus (Linnaeus, 1758) (Sedivy, 1967), Callidium aeneum (De Geer, 1775) (Campadelli \& Scaramozzino, 1994), Molorchus umbellatarum (Schreber, 1759) on Malus domestica (Borkh., 1803) (Strojnowski, 1977). In addition, two plant are reported to be associated with this species by Pisica (1969): Alnus glutinosa (L.) Gaerth, 1790 and Corylus avellana Linnaeus, 1753. Here we provide additional host and plant association records for Xorides gravenhorstii: the species was reared from Prunus persica and buprestid beetle larva for the first time.

The genus Poemenia from the subfamily Poemeniinae numbers only four species in Europe, of which at least two species, $P$. notata and $P$. collaris (Haupt, 1917), were reared from trap-nests inhabited by the crabronid wasps, Passaloecus eremita Kohl, 1893 and P. corniger Shuckard, 1837 (Schmidt \& Zmudzinski, 1983). Jussila and Kapyla (1975) reported $P$. notata as a parasitoid of another crabronid, Trypoxylon figulum (Linnaeus, 1758). In addition, the first author has a specimen of Poemenia collaris reared from trap-nests in Ukraine. On the other hand, he saw the $P$. notata specimen reared from the buprestid species in Georgia (Varga, in prep.) and several cerambycids species, Acanthocinus aedilis (Linnaeus, 1758), Arhopalus rusticus (Linnaeus, 1758) and Asemum striatum (Linnaeus, 1758) are reported as hosts of $P$. notata by R. Uhthoff-Kaufmann (1991). The male specimen of $P$. notata reported in this study was reared together with Dolichomitus specimens from logs of Prunus cerasifera infested by Ptosima undecimmaculata. Unfortunately, little is known about biology of poemeniines and thus, direct observation of parasitoid larva is needed 
New Distributional, Host and Plant Association Records

to confidently state about host-parasitoid interactions of the current species. Thus, in this paper we just reported the new plant association, Prunus cerasifera, for the observed Poemeniine wasp.

\section{AKNOWLEDGEMENTS}

The authors are deeply grateful to Prof. Göksel TOZLU (Atatürk University, Faculty of Agriculture, Department of Plant Protection, Erzurum, Turkey) for the host insect identification; and to Brian L Fisher (California Academy of Sciences, Department of Entomology, San Francisco) for access to digital imaging system temporarily provided for SIZK.

\section{REFERENCES}

Aubert, J.F. (1969). Les Ichneumonides ouest-palearctiques et leurs hotes 1. Pimplinae, Xoridinae, Acaenitinae. Laboratoire d'Evolution des Etres Organises, Paris, 302 pp.

Bolu, H. (2008). A new host, Sphenoptera tappesi Marseul (Coleoptera: Buprestidae), for Dolichomitus kriechbaumeri (Schulz) (Hymenoptera: Ichneumonidae) from Turkey. Turkish Journal of Zoology, 32(2), 225-226

Campadelli, G. \& Scaramozzino, E.P.L. (1994). Parasitic Hymenoptera of xylophagous insects in Romagna. Bollettino dell'Istituto di Entomologia della Universita degli Studi di Bologna, 48, 115-121.

Çoruh, S. (2010). Composition, habitat distribution and seasonal activity of Pimplinae (Hymenoptera: Ichneumonidae) in North-East Anatolia region of Turkey. Anadolu Journal of Agriculture Sciences, 25(1), 28-36.

Çoruh, S., Kolarov, J. \& Özbek, H. (2014). The fauna of Ichneumonidae (Hymenoptera) of eastern Turkey with zoogeographical remarks and host data. Journal of Insect Biodiversity, 2(16), 1-21. http://dx.doi. org/10.12976/jib/2014.2.16

Çoruh, S. \& Kolarov, J. (2013). New data on Turkish Acaenitinae (Hymenoptera: Ichneumonidae) with description of a new species. Zoology in the Middle East, 59(3), 261-265.

Çoruh, S. \& Kolarov, J. (2010). A review of the Turkish Orthopelmatinae (Insecta: Hymenoptera: Ichneumonidae). Scientific Research and Essays, 5(22), 3518-3521.

Jussila, R. \& Kapyla, M. (1975). Observations on Townesia tenuiventris (HImgr.) (Hym., Ichneumonidae) and its hosts Chelostoma maxillosum (L.) (Hym., Megachilidae) and Trypoxylon figulus (L.) (Hym., Sphecidae). Annales Entomologici Fennici, 41,81-86.

Kolarov, J.A. (1995). A catalogue of the Turkish Ichneumonidae (Hymenoptera). Entomofauna, 16(7),137-188.

Kolarov, J., Çoruh, S., Yurtcan, M., \& Gürbüz, M. F. (2009). A study of Metopiinae from Turkey with description of a new species (Hymenoptera: Ichneumonidae). Zoology in the Middle East, 46, 75-82.

Leclercq, J. (1945). Note sur le Xestobium plumbeum Illig. Bulletin et annales de la Société royale belge d'entomologie, 81(11/12), 228.

Pisica, C. (1969). Especes d'Ephiltinae, Xoridine et Lissontinae (Hym. Ichneum.) nouvelles et rares pour la Faune de la Roumanie. Analel Stiintifice ale Universitatii 'Al. I. Cuza' din lasi. Sect. II a, 15, 87-92.

Schmidt, K. \& Zmudzinski, F. (1983). Beiträge zur Kenntnis der badischen Schlupfwespenfauna (Hymenoptera, Ichneumonidae). 1. Xoridinae, Acaenitinae, Pimplinae (Poemeniini, Rhyssini). Andrias, 3, 97-103.

Sedivy, J. (1967). Contribution to the knowledge of the hosts of Ichneumon flies II. Zpravy Ceskoslovenske Spolecnosti Entomologicke Pri CSAV, 3, 5-11. 
Strojnowski, R. (1977). Hymenopterans (Hymenoptera, Parasitica) parasitizing fruit tree pests: I. Parasites of Molorchus ubellatarum Schreber (Coleoptera, Cerambycidae), a pest of the apple tree Malus domestica Borb. Polskie Pismo Entomologiczne, 47(1), 137-146.

Uhthoff-Kaufmann, R.R (1991). The distribution and occurrence of Acanthocinus Dej. and Agapanthia Serv. (Col.: Lamiidae) in the British Isles. Entomologist's Record, 103, 189-192.

Varga O. (2012). The genus Dolichomitus Smith, 1877 (Hymenoptera: Ichneumonidae: Pimplinae) in the Ukrainian Carpathians, with description of a new species. Zoologische Mededelingen, 86(7), 569-578.

Yu, D.S., van Achterberg, C. \& Horstmann, K. (2016). World Ichneumonoidea 2015. Taxonomy, Biology, Morphology and Distribution. Nepean, Ontario. [program]

Zwakhals, K. (2010). Identification of Western Palearctic Dolichomitus species (Hymenoptera: Ichneumonidae: Pimplinae). Entomologische Berichten. Amsterdam, 70(4), 111-127. 